\title{
FEATURES OF PHYSICAL AND MECHANICAL PARAMETERS OF ACRYLIC PLASTICS AFTER FULLERENE COATING
}

DOI: 10.36740/WLek202006103

\author{
Bohdan Yu. Sylenko, Valentyn M. Dvornyk, Yurii I. Sylenko, Maryna V. Khrebor, Tetiana A. Khmil, Volodymyr I. Makarenko \\ UKRAINIAN MEDICAL STOMATOLOGICAL ACADEMY, POLTAVA, UKRAINE
}

\begin{abstract}
The aim of the research is to study the physical and mechanical parameters of the bases in removable laminar dentures after modification of their surface.

Materials and methods: the studied samples were divided into two groups (group I-acrylic plastics, and group II - acrylic plastics with fullerene $\mathrm{C}_{60}$ nanocoating), 50 samples in each group. The coefficients of water absorption, water solubility, microhardness and deformation characteristics of materials were studied.

Results and conclusions: The material covered with fullerene $C_{60}$ has a lower coefficient of water absorption and water solubility, which amounted to $0.55 \%$ and $0.23 \%$ respectively, from the initial weight of samples, as compared with acrylic plastics without coating ( $0.71 \%$ and $034 \%$, respectively). The strength parameters of samples of group

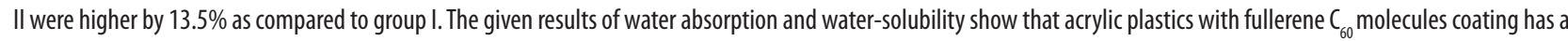
lower coefficient of water absorption and water solubility, in comparison with acrylic plastics without coating. This indicates a higher degree of resistance to biodegradation of the modified surface material, in turn reducing the washing-out of residual monomer from the denture, which directly improves the strength parameters of the acrylic plastics and can prevent the development of denture stomatitis.
\end{abstract}

KEY WORDS: acrylic plastics, water absorption, water solubility, nanocoating with fullerene $C_{60}$

Wiad Lek. 2020;73(6):1097-1102

\section{INTRODUCTION}

The quality prosthetics with partial and complete removable laminar dentures is an important issue in the clinical practice of orthopedic dentistry. According to various authors, the need for such types of structures varies from 50 to $75 \%$ of the total number of orthopedic patients $[1,2,3]$.

Currently, the main materials used for manufacturing removable dentures are derivatives of acrylic and methacrylic plastics: from 91 to $98 \%$ of removable dentures are made of acrylic plastics $[4,5,6]$.

The extensive period of using acrylic plastics in orthopedic dentistry as the main material for manufacturing various types of dentures since the 1930s and up to this day indicates its satisfactory biological, physical and mechanical properties. It meets the requirements of everyday dentistry because of its relatively good biocompatibility, chemical inertness, favorable mechanical properties, stable dimensions, aesthetic, technological benefits, the possibility to fix it, as well as its low cost $[7,8,9]$.

However, among the list of positive qualities of acrylic plastics, there are certain shortcomings. This is supported by the fact that more than $26 \%$ of patients cannot use removable dentures, and $37 \%$ are forced to adjust to poorly-designed dentures $[2,10]$.

The disadvantages of acrylic prosthesis include inaccurate correspondence of the prosthetic base of the relief of the tissues of the prosthetic bed, inadequate pressure, insufficient mechanical strength, the presence of residual monomer, disruption of thermoregulation, microbiological imbalance and biodegradation $[11,12,13,14]$.

In order to improve the strength parameters and reduce the degree of water absorption of plastics, we developed a new way of enhancing the removable laminar denture, manufactured according to traditional technology using the nanosized material - molecules of fullerene $\mathrm{C}_{60}$.

\section{THE AIM}

The aim of the research is to study the physical and mechanical parameters of the bases in removable laminar dentures after the modification of their surface

\section{MATERIALS AND METHODS}

We used the following samples of materials: acrylic plastics; and acrylic plastics, coated with a layer of fullerene $\mathrm{C}_{60}$ nanomaterial.

The study of certain physical and mechanical properties was conducted in accordance with the general requirements of GOST 143559-79, as well as GOSTs for testing each indicator on carefully selected samples without cracks, pores and other defects.

Samples of acrylic plastics, and acrylic plastics with fullerene $\mathrm{C}_{60}$ nanocoating were obtained using the following technological methods:

1. Polymerization of acrylic plastics by the compression method of forming plastic paste in the cuvette. 
2. Coverage of polymerized acrylic plastics with molecules of fullerene $\mathrm{C}_{60}$, by the method of magnetron sputtering of materials.

Measurement of the thickness of samples was conducted using the micrometer with accuracy up to $0.001 \mathrm{~mm}$.

According to the materials and methods of manufacturing, the samples were divided into two groups of 50 samples in each:

Group I - samples made of acrylic plastics

Group II - samples made of acrylic plastics with fullerene $\mathrm{C}_{60}$ nanocoating.

\section{DETERMINING THE COEFFICIENTS OF WATER ABSORPTION AND WATER SOLUBILITY}

Before testing, the samples were conditioned according to GOST 12423-66 for at least 16 hours (at the temperature of $23 \pm 2^{\circ} \mathrm{C}$ and relative humidity of $50+5 \%$ ). The length, width and thickness of the samples were measured using micrometer MK 0-25 GOST 6507-78 with accuracy of \pm $0.01 \mathrm{~mm}$ in at least three places.

To determine water absorption and water solubility, the samples were immersed in distilled water for 30 days at the temperature of $37^{\circ} \pm 1^{\circ} \mathrm{C}$ in a dry air thermostat, so that the samples did not touch the walls of the Petri glass cup, each other and the surface of water. The initial mass $\left(\mathrm{m}_{0}\right)$ of samples was determined by weighing them on scales of class II with an error of not more than $0.2 \mathrm{mg}$. At the end of this period, samples were removed and gently wiped with dry filter paper. After $1 \mathrm{~min}$ after removing samples from water, they were weighed with the same precision as in the beginning, determining the mass $\mathrm{m}_{1}$. After weighing, the samples were again conditioned to the constant mass in the exicator, as described above. The constant mass was recorded as $\mathrm{m}_{2}$. Water absorption $\left(\mathrm{W}_{\mathrm{a}}\right.$, in $\left.\mu \mathrm{g} / \mathrm{mm}^{3}\right)$ was calculated by the formula: $\mathrm{W}_{\mathrm{a}}=\frac{m_{0}-m_{1}}{V}$, where $m_{0}$ is the initial mass of the sample, $m_{1}$ is the sample mass after exposure in water for 30 days, $V$ is the volume of the sample. Water solubility $\left(\mathrm{W}_{\mathrm{s}}\right.$, in $\left.\mu \mathrm{g} / \mathrm{mm}^{3}\right)$ was calculated by the formula: $\mathrm{W}_{\mathrm{s} 1}=\frac{m_{0}-m_{2}}{v}$, where $m_{0}$ is the initial mass of the sample, $m_{2}$ is the sample mass after exposure in water for 30 days and drying, $V$ is the volume of the sample.

For the study of microhardness (in $\mathrm{mPa}$ ), samples of the studied materials were additionally grinded and polished to a mirror luster.

Microhardness of the examined samples was studied according to the Vickers method with the microtrometer PMT-3, by the size of the imprint of the diamond pyramid (indenter) at different loads.

The sample was placed on the microscope stage, whose rotation led the sample to the diamond pyramid, lowering it to the sample, which was examined so that the distance between the center of the imprint and the edge of the sample was not less than $2-2.5 \mathrm{~mm}$. The load time was 10 seconds. Measurements of microhardness were carried out at three points of each sample. After the sample was released from the load, the microscope stage was brought to the microscope's eyepiece. The imprint was measured with the accuracy up to $0.3 \mu \mathrm{m}$.

The value of microhardness by Vickers $(\mathrm{Hv}, \mathrm{mPa})$ was determined by the formula:

$$
H v=\frac{18540 P}{2 a^{2}}
$$

where $\mathrm{P}$ is load, g;

$2 \mathrm{a}$ is arithmetic average of the diagonals length, $\mu \mathrm{m}$.

For each of the studied samples, we obtained three imprints and found the average value.

The deformation characteristics of all groups of studied samples were examined in their deformation in terms of compression and tension. The study of deformation characteristics of the examined samples in terms of compression was conducted using the deformation machine MRK-1. To determine the compression deformation, samples of materials were cylinders of $4 \times 4 \times 10 \mathrm{~mm}$. The deformation rate was $0.1 \mathrm{~mm} / \mathrm{min}$.

The value of the resilience boundary was determined by the formula:

$$
\sigma_{r s}=\frac{P_{0}}{S_{0}}
$$

where $\mathrm{P}_{\mathrm{o}}$ is the load at which the first deviation from the linearity on the deformation curve $(\mathrm{H})$ is observed;

$\mathrm{S}_{\mathrm{o}}$ is the initial plane of the cross-sectional sample $\left(\mathrm{m}^{2}\right)$.

Tension deformation was conducted in the discontinuous facility MRK- 1 with the deformation rate of $0.2 \mathrm{~mm} / \mathrm{min}$ on the dumbbell shaped samples with the dimensions of the working part of $14 \times 10 \times 3 \mathrm{~mm}$. The samples were fastened to the clamp of the test machine in such a way that the larger axis of the sample coincided with the loading axle. The tightening of the clamps did not allow the sample to slip during the test.

According to the obtained deformation curves, we determined the yielding boundary $\left(\sigma_{0.2}\right)$, the strength boundarv $\left(\sigma_{\mathrm{st}}\right)$ and the maximum deformation to destruction $\Sigma_{\text {max }}$.

To determine the strength boundary, in the formula $\mathrm{P}$ 。 was substituted with $\mathrm{P}_{\max }$ - the load at which the sample is destroyed.

The study of bending deformation characteristics was also carried out in the MRK-1 facility with an aperture for four-point bending. To this end, samples of materials $35 \times 5 \times 3 \mathrm{~mm}$ from different groups were used.

To determine the reliability of the research results, the variational-statistical analysis was used for interrelated observations, calculating the reliability of difference according to Student. Statistical processing was conducted using the STATISTICA 6.0 (StatSoft, USA) software with a mean (M) and a standard error $(\mathrm{m})$. Differences between the groups were considered statistically significant at $\mathrm{p}<0.05$.

\section{RESULTS}

Indicators of water absorption and water solubility are presented in Table I.

Based on the data presented in Table I, the average initial mass of samples of acrylic plastics material was $348.8 \pm 10.3 \mathrm{mg}$. After 
Table I. Average values of main characteristics of sample materials acrylic plastics and acrylic plastics with fullerene $\mathrm{C}_{60}$ molecules coating and indicators of water absorption and water solubility on the 30th day of the experiment

\begin{tabular}{|c|c|c|c|c|c|c|c|c|c|c|}
\hline No & $\begin{array}{c}\text { Title of the } \\
\text { material }\end{array}$ & a, $\mathrm{mm}$ & b, $\mathbf{m m}$ & $\mathrm{h}, \mathrm{mm}$ & $\mathbf{V}, \mathbf{m m}^{3}$ & $\mathrm{~m}_{0^{\prime}}, \mathrm{mg}$ & $m_{1}, m g$ & $\mathrm{~m}_{2}, \mathrm{mg}$ & $\begin{array}{c}W_{\mathrm{a}^{\prime}} \\
\mu \mathrm{g} / \mathrm{mm}^{3}\end{array}$ & $\begin{array}{c}W_{\mathrm{sl}^{\prime}} \\
\mu \mathrm{g} / \mathrm{mm}^{3}\end{array}$ \\
\hline 1 & Acrylic plastics & $\begin{array}{c}6.1 \\
\pm 0.05 \\
\end{array}$ & $\begin{array}{r}3.5 \\
\pm 0.02 \\
\end{array}$ & $\begin{array}{r}14.7 \\
\pm 0.5 \\
\end{array}$ & $\begin{array}{c}315 \\
\pm 9.26 \\
\end{array}$ & $\begin{array}{l}348.8 \\
\pm 10.3\end{array}$ & $\begin{array}{l}351.3 \\
\pm 10.4\end{array}$ & $\begin{array}{l}347.6 \\
\pm 10.3\end{array}$ & $\begin{array}{c}7.80 \\
\pm 0.27\end{array}$ & $\begin{array}{c}3.87 \\
\pm 0.18\end{array}$ \\
\hline 2 & $\begin{array}{l}\text { Acrylic } \\
\text { plastics with } \\
\text { nanocoating }\end{array}$ & $\begin{array}{c}6.24 \\
\pm 0.07 \\
p>0.05\end{array}$ & $\begin{array}{c}3.47 \\
\pm 0.01 \\
p>0.05\end{array}$ & $\begin{array}{c}16.1 \\
\pm 0.26 \\
p<0.05\end{array}$ & $\begin{array}{c}348.5 \\
\pm 3.86 \\
p<0.05\end{array}$ & $\begin{array}{c}382.1 \\
\pm 6.2 \\
p<0.05\end{array}$ & $\begin{array}{c}384.2 \\
\pm 6.3 \\
p<0.05\end{array}$ & $\begin{array}{c}381.2 \\
\pm 6.1 \\
p<0.05\end{array}$ & $\begin{array}{c}5.90 \\
\pm 0.30 \\
p<0.05\end{array}$ & $\begin{array}{c}2.57 \\
\pm 0.28 \\
p<0.05\end{array}$ \\
\hline
\end{tabular}

Table II. Average values of microhardness indicators in the presented materials $(M \pm m, n=10)$

\begin{tabular}{cc}
\hline Title of the material & $\mathbf{H}_{\mathbf{v}^{\prime}} \mathbf{M p a}$ \\
\hline Acrylic plastics & $307.3 \pm 6.5$ \\
\hline Acrylic plastics with nanocoating & $701.8 \pm 13.1$ \\
$\mathrm{p}<0.05$ \\
\hline
\end{tabular}

Table III. Average values of strength and plasticity of samples made of the examined materials in the tension study $(M \pm m, n=10)$

\begin{tabular}{|c|c|c|c|c|c|}
\hline Title of the material & $\begin{array}{c}\text { Young's modulus, } \\
\text { E, MPa }\end{array}$ & ors., MPa & $\sigma 02, \mathrm{MPa}$ & ost., MPa & $\delta, \%$ \\
\hline Acrylic plastics & $241.78 \pm 0.55$ & $36.02 \pm 1.01$ & $37.25 \pm 1.35$ & $40.25 \pm 1.06$ & $0.38 \pm 0.038$ \\
\hline $\begin{array}{l}\text { Acrylic plastics with } \\
\text { nanocoating }\end{array}$ & $\begin{array}{c}356.15 \pm 9.39 \\
p<0.05\end{array}$ & $\begin{array}{c}36.54 \pm 1.30 \\
p>0.05\end{array}$ & $\begin{array}{c}38.40 \pm 1.47 \\
p>0.05\end{array}$ & $\begin{array}{c}53.16 \pm 1.59 \\
p<0.05\end{array}$ & $\begin{array}{c}3.20 \pm 0.41 \\
p<0.05\end{array}$ \\
\hline
\end{tabular}

Table IV. Average values of the strength and plasticity of samples made of the examined materials in the compression study $(M \pm m, n=10)$

\begin{tabular}{|c|c|c|c|c|}
\hline Title of the material & $\begin{array}{c}\text { Young's modulus, } \\
\mathrm{E}, \mathrm{MPa}\end{array}$ & ors., $\mathrm{MPa}$ & $\sigma 02, \mathrm{MPa}$ & ost., $\mathrm{MPa}$ \\
\hline Acrylic plastics & $939.72 \pm 9.09$ & $59.96 \pm 2.42$ & $62.76 \pm 2.38$ & $95.32 \pm 1.9$ \\
\hline $\begin{array}{l}\text { Acrylic plastics with } \\
\text { nanocoating }\end{array}$ & $\begin{array}{c}952.44 \pm 12.32 \\
p>0.05\end{array}$ & $\begin{array}{c}64.67 \pm 2.01 \\
p>0.05\end{array}$ & $\begin{array}{c}67.18 \pm 2.06 \\
p>0.05\end{array}$ & $\begin{array}{c}89.70 \pm 1.74 \\
p<0.05\end{array}$ \\
\hline
\end{tabular}

Table V. Average values of strength and plasticity of samples made of the examined materials in the bending study $(M \pm m, n=10)$

\begin{tabular}{|c|c|c|c|c|}
\hline Title of the material & $\begin{array}{c}\text { Young's modulus, } \\
\mathrm{E}, \mathrm{MPa}\end{array}$ & ors., MPa & ost., MPa & $\mathbf{w}_{\text {max }^{\prime}}, \mathrm{mm}$ \\
\hline Acrylic plastics & $635.8 \pm 13.71$ & $48.8 \pm 0.83$ & $72.5 \pm 1.77$ & $5.08 \pm 0.05$ \\
\hline $\begin{array}{l}\text { Acrylic plastics with } \\
\text { nanocoating }\end{array}$ & $\begin{array}{c}1135.4 \pm 11.33 \\
p<0.05\end{array}$ & $\begin{array}{c}56.4 \pm 0.6 \\
p<0.05\end{array}$ & $\begin{array}{c}105.3 \pm 0.89 \\
p<0.05\end{array}$ & $\begin{array}{l}4.99 \pm 0.1 \\
p>0.05\end{array}$ \\
\hline
\end{tabular}

30 days of exposure in distilled water at $37^{\circ} \pm 1^{\circ} \mathrm{C}$, the average sample mass increased to $351.3 \pm 10.4 \mathrm{mg}$, and after conditioning the samples to constant mass in the exicator, their average mass decreased to $347.6 \pm 10.3 \mathrm{mg}$. Accordingly, the coefficient of water absorption on the 30th day was $7.80 \pm 0.27 \mu \mathrm{g} / \mathrm{mm}^{3}$, and the coefficient of water solubility was $3.87 \pm 0.18 \mu \mathrm{g} / \mathrm{mm}^{3}$.

The average initial mass of samples of acrylic plastics material with fullerene $\mathrm{C}_{60}$ molecules nanocoating was $382.1 \pm 6.2 \mathrm{mg}$. After 30 days of exposure in distilled water at $37^{\circ} \pm 1^{\circ} \mathrm{C}$, the average sample mass increased to $384.2 \pm$ $6.3 \mathrm{mg}$, and after conditioning the samples to constant mass in the exicator, their average mass decreased to $381.2 \pm 6.2$ mg Accordingly, the coefficient of water absorption on the 30th day was $5.90 \pm 0.30 \mu \mathrm{g} / \mathrm{mm}^{3}$, and the coefficient of water solubility was $2.57 \pm 0.28 \mu \mathrm{g} / \mathrm{mm}^{3}$.

The obtained data show that the material covered with fullerene $\mathrm{C}_{60}$ has a lower coefficient of water absorption and water solubility, which amounted to $0.55 \%$ and $0.23 \%$, respectively, than the initial weight of samples, as compared with acrylic plastics without coating $-0.71 \%$ and $034 \%$, respectively.

The study of microhardness allows us to evaluate the properties of thin surface layers of dental base materials, that is, their ability to resist local plastic deformation, which arises under the influence of the action of more solid materials.

As our studies have shown (Table II), the microhardness indicators of base material samples are significantly higher in Group II, as compared with Group I. The average value of microhardness is $307.3 \pm 13.3 \mathrm{mPa}$, in the second group $701.8 \pm 26.6$, which is by 2.28 times higher than in the second group.

In the study of tension deformation of the materials, it was determined that samples of basic materials are de- 
stroyed when stretching after plastic deformation within the range of $0.38-3.20 \%$, which makes it possible to determine the strength of the materials under examination. It should be noted that samples of acrylic plastics are destroyed at plastic deformation of $0.38 \%$, and samples of acrylic plastics with nanocoating at plastic deformation of $3.20 \%$ (Table III).

From the data given in the table it is established that the type of material significantly influences the strength value of the base material samples: acrylic plastics and with nanocoating. The plastic deformation is somewhat higher in the sample with nanocoating.

As shown by the conducted studies, compression deformation characteristics, for each of ten samples of basic materials, and with fullerene $\mathrm{C}_{60}$ nanocoating, differences in strength and compression deformation were not significant (Table IV).

The result of the bending study is the arithmetic mean of the values in the destructive stress on the bend of the experimental samples from each group. We found that the magnitude of the force, applied to the samples in the second group, leading to deformation, is by $13.5 \%$ higher than in the first group (Table V).

\section{DISCUSSION}

As a result of the combined effect of the prosthesis on the tissues of the prosthetic bed, complications may arise when used, such as denture stomatitis $[4,15]$. The percentage of symptoms of denture stomatitis in patients using removable laminar dentures varies according to various authors within $15-70 \%[16,17]$.

One of the main causes of denture stomatitis is the presence of a residual monomer in the prosthesis. The residual monomer is the amount of monomer that is not connected to the polymer during the polymerization process. Incomplete polymerization of acrylates reduces the physical, mechanical and biological properties of dentures. The monomer can be washed into saliva and cause cytotoxic effects in the oral cavity. The higher the number of monomers that have not reacted, the higher will be the harmful effect $[18,19,20]$.

In case of disrupted polymerization regime, the prosthetic base may contain from 3.4 to $8 \%$ free monomer, which is released from the denture for 5 years. But even in case of correct mode and advanced polymerization techniques, up to $0.5 \%$ of residual monomer remains in the plastic [15,21].

There are two indicators that affect the amount and rate of leaching of the residual monomer in the oral cavity: water absorption - the ability of the material to saturate and retain water over time and water solubility - the number of components of the material that is washed away and replaced by water molecules [22].

The main component of saliva is water, which is one of the main factors of biodestruction of acrylic dentures. Water molecules can easily penetrate into the polymeric network, which allows the removal of unbound monomer or other components of the plastics. It takes from one to two months after the start of using a denture to saturate polymer with water. The mouth fluid, as physiologically active, provokes the release of toxic substances from the denture polymeric bases more than the neutral extractant - distilled water [23].

The excess content of residual monomer and the degree of water absorption affect the strength parameters of denture. The strength of denture decreases with excessive content of residual monomer, resulting in its deformation under load. In addition, monomer is washed primarily from the surface of the prosthetic base, and thus the structure of the polymer dissolves, creating tension that ultimately leads to decreased strength. In orthopedic structures, this tension over time causes cracking and breakage of the bases of dentures [24].

Fractures of dentures reach $15 \%$ in the first year of use. Breakdowns of plastic bases make up 35-49\% of the total number of manufactured removable laminar dentures. Duration of using the removable laminar dentures until the first break is on average 0.5-1.4 years [10,25].

Since currently there is no material that could replace acrylic plastics, an important task is to improve its biological, physical and mechanical properties. Thus, it is possible to increase the parameters of strength and reduce water absorption of plastic by means of a new way of improving the removable laminar dentures, produced according to the traditional technology, with nanosized material - molecules of fullerene $\mathrm{C}_{60}$.

\section{CONCLUSIONS}

1. The given results of water absorption and water solubility show that acrylic plastics with fullerene $\mathrm{C}_{60}$ nanocoating has a lower coefficient of water absorption and water solubility, as compared to acrylic plastics without coating. This indicates a higher degree of resistance to biodegradation of the modified surface material, in turn reducing the washing-out of residual monomer from the denture, which directly improves the strength parameters of the acrylic plastics.

2. The obtained data prove that nanocoated plastics have higher physical-mechanical characteristics as compared to conventional plastics. The microhardness index is by 2.28 times higher in modified plastics, indicating a better surface ability to withstand mechanical stresses directed on the surface, without changing the surface structure.

3. Samples with nanocoating are more resistant to destruction because the index of relative residual deformation prior to the sample destruction is by $2.82 \%$ higher than in conventional plastics. Therefore, it can be argued that such material can be used in dentistry to reduce the number of breakages of removable dentures and prolong their lifetime.

\section{REFERENCES}

1. Zholudev S.Ye. Sposoby lecheniya neperenosimostis"yemnykh zubnykh protezov [Methods of treating intolerance to removable dentures]. Panorama of prosthetic dentistry. 2003; 3: 28-34. (In Russian). 
2. Bocharov V.S., Moskvin Yu.N., Kim A.R. Vliyaniye bazisnykh materialov s"yemnykh protezov na parametri imunnogo gomeostaza slizistoy obolochki rta [Influence of base materials of removable dentures on the parameters of immune homeostasis of the oral mucosa]. Pacific Medical Journal. 2014; 3: 62-64. (In Russian).

3. Rozumenko V.A. Klinicheskaya aprobatsiya usovershenstvovannogo metoda izgotovleniya polnogo s'yemnogo plastinochnogo proteza pri neperenosimosti akrilovoy plastmassy [Clinical testing of an improved method of manufacturing a complete removable laminar prosthesis in case of intolerance to acrylic plastic]. Ukrainian Dental Almanakh. 2011; 4: 42-45. (In Russian).

4. Paliychuk I.V. Analiz vykorystannya riznykh vydiv ortopedychnykh konstruktsiy ta yikh vplyv na slyzovu obolonku porozhnyny rota [Analysis of the use of various types of orthopedic structures and their influence on the oral mucosa]. Dental news. 2015; 2 (83): 17-18. (In Ukrainian).

5. Zholudev S.Ye. Rabochaya klasifikatsiya zabolevaniy slizistoy obolochki proteznogo lozha u lits, pol'zuyushchikhsya s"yemnymi akrilovymi protezami [The working classification of diseases of the mucous membrane of the prosthetic bed in persons using removable acrylic prostheses]. Dentistry problems. 2005; 3: 40-43. (In Russian).

6. Bayraktar, Guvener B, Bural C. Influence of polymerization method, curing process, and length of time of storage in water on the residual methyl methacrylate content in dental acrylic resins. J Biomed Mater Res B Appl Biomater. 2006;76:340-345.

7. Nidzelskyy M.Ya., Davydenko V.Yu., Davydenko H.M. Porivnyal'na kharakterystyka rivnya zalyshkovoho monomeru v bazysakh znimnykh proteziv iz akrylovykh plastmas, vyhotovlenykh za riznymy tekhnolohiyamy polimeryzatsiyi [Comparative characteristics of the residual monomer level in the bases of removable prostheses made of acrylic plastics, made according to different polymerization technologies]. Bulletin of Biology and Medicine. 2014; 2(2): 45-48. (In Ukrainian).

8. Kostik M., Pejcic A., Igic M. Adverse reactions to denture resin materials. European Review for Medical and Pharmacological Sciences. 2017; 21:5298-5305.

9. Labunets' V. A. Kozlov 0. V., Shabliy V. F. et al. Zahal'ni polozhennya zabezpechennya systemy yakosti v zubotekhnichnomu vyrobnytstvi [General Provisions for Quality Assurance in Dental Engineering]. Visnyk stomatolohiyi.2010; 1: 49-51. (In Ukrainian).

10. Mikhaylova S. G. Razvitiye i formirovaniye atrofii proteznogo lozha pod bazisami polnykh s"yomnykh protezov v zavisimosti ot tekhnologii ikh izgotovleniya [The development and formation of atrophy of the prosthetic bed under the bases of complete removable prostheses depending on the technology of their manufacture]. Tauride medicalbiological bulletin. 2009; 4(48): 141-144. (In Russian).

11. Vakhnenko 0. M. Analiz stanu normatyvnoyi bazy, shcho rehulyuye nadannya stomatolohichnoyi dopomohy naselennyu Ukrayiny [Analysis of the status of the normative base that regulates the provision of dental care to the Ukrainian population]. Sovremennaya stomatolohyya. 2009; 4: 145-147. (In Ukrainian).

12. Gozhaya L.D. Allergicheskiye i toksiko-khimicheskiye stomatity, obuslovlennyye materialami zubnykh protezov : metod. posobiye dlya vrachey stomatologov. [Allergic and toxic-chemical stomatitis caused by the materials of dentures: method]. Moscow; 2001, 31 p.

13. Gonçalves T.S., Morganti M.A., Campos L.C. Allergy to auto-polymerized acrylic resin in an orthodontic patient. Am J Orthod Dentofacial Orthop. 2006;129:431-435.
14. Krychka N.V. Problema vidpovidnosti proteznomu lozhu, mitsnosti ta biolohichniy indyferentnosti proteziv iz akrylovykh plastmas [The problem of the suitability of the prosthetic bed, durability and biological indifference of the prosthetics from acrylic plastics]. Problems of Continuous Medical Education and Science. 2015; 3: 79-82. (In Ukrainian).

15. Sokolovs'ka V. M., Nidzel's'kyy M. YA., Dudchenko M. 0. Vplyv akrylovykh plastmas na slyzovu obolonku porozhnyny rota [Influence of acrylic plastics on the mucous membrane of the oral cavity]. Dermatovenereology. Cosmetology. Sexual pathology. 2015; 3-4: 212215. (In Ukrainian).

16. Chirkova N.V., Komarova Yu. N. Analiz faktorov, vliyayushchikh na period adaptatsii u patsiyentov so s"yemnymi plastinochnymi protezami [Analysis of factors affecting the adaptation period in patients with removable laminar prostheses]. Modern orthopedic dentistry. 2011;15:50. (In Russian).

17. Zverkhanovskiy A.A., Yarovaya A.V., Maksimenko P.V. Optimizatsiya konstruktsii polnogos"yemnogo proteza s tsel'yu profilaktiki proteznykh stomatitov. [0ptimization of the design of a complete removable prosthesis for the prevention of prosthetic stomatitis]. Ukraíns'kiy stomatologíchniy al'manakh. 2016; 3: 30-35. (In Russian).

18. Rashid H., Sheikh Z., Vohra F. Allergic effects of the residual monomer used in denture base acrylic resins. Eur J Dent. 2015; 9: 614-619.

19. Neves C.B., Lopes L.P., Ferrao H.F. et al. Ethanol postpolymerization treatment forimproving the biocompatibility of acrylic reline resins. Biomed Res Int. 2013;2013:485246.

20. NikTH, Shahroudi AS, EraghihzadehZ, Aghajani F. Comparison of residual monomer loss from cold-cure orthodontic acrylic resins processed by different polymerization techniques. J Orthod. 2014;41:30-7.

21. Romanova Yu.G., Novitskaya I.K., Vit V.V. Deystviye metilmetakrilata na slizistuyu obolochku polosti rta (morfologicheskoye issledovaniye). [Effects of methyl methacrylate on the oral mucosa (morphological study) Experimental and clinical medicine. 2012; 4: 50-53. (In Russian).

22. Bettencourt A.F., Pincheiro L.M., Castro M.F. et al. Biodegradation of acrylic based resins. Dental Materials. 2010;26(5):171-180.

23. Blanca Liliana Torres León, Altair Antoninha Del Bel Cury, Renata Cunha Matheus Rodrigues Garcia. Loss of residual monomer from resilient lining materials processed by different methods. Rev Odonto Ciênc 2008;23:215-9.

24. Mal'ginov N.N., Podkolzin A.A., Lebedenko I.Yu. Sanitarno-khimicheskiye svoystva bazisnykh plastmass v zavisimosti ot rezhimov polimerizatsii. [Sanitary-chemical properties of basic plastics, depending on the modes of polymerization]. Russian dental journal. 2000; 1:11-15. (In Russian).

25. Kuznetsov V.V., Pysarenko 0.A. Udoskonalennya tekhnolohiyi pokrashchennya yakosti bazysiv znimnykh plastynkovykh proteziv. [ Improving the technology of improving the quality of the bases of removable plate prostheses]. Ukrainian Dental Almanac. 2011; 1:61-63. (In Ukrainian).

The work was performed within the research work "Application of materials filled with nanoparticles in dentistry" State registration number $0116 U 004189$ (article), the work was performed at their own expense.

\section{ORCID and contributorship:}

Bohdan Yu. Sylenko - 0000-0003-4435-0160 A,B,C,D,E

Valentyn M. Dvornyk - 0000-0002-3693-2403 A,B,C,D,E

Yurii I. Sylenko - 0000-0002-2955-8820 A,B,C,D,E 
Maryna V. Khrebor - 0000-0001-5958-2672 B,D,E,F

Tetiana A. Khmil - 0000-0001-5673-3535 B,D,E,F

Volodymyr I. Makarenko - 0000-0001-5591-6145 B,C

\section{Conflict of interest:}

The Authors declare no conflict of interest.

\section{CORRESPONDING AUTHOR}

Yurii I. Sylenko

Ukrainian Medical Stomatological Academy

Shevchenko str. 23, 36011 Poltava, Ukraine

tel: +380675321081

e-mail: silenko@gmail.com

Received: 05.02.2020

Accepted: 04.05 .2020 